\title{
MOLECULAR SCREENING OF Plasmodium sp. ASYMPTOMATIC CARRIERS AMONG TRANSFUSION CENTERS FROM BRAZILIAN AMAZON REGION
}

\author{
Érica FUGIKAHA(1), Patrícia Aparecida FORNAZARI(1), Roberta de Souza Rodrigues PENHALbEL(1), Alexandre LORENZETTI(1), Roberto Duarte MAROSO(2), \\ Juvanete Távora AMORAS(3), Ana Sueli SARAIVA(4), Rita Uchôa da SILVA(5), Cláudia Regina BONINI-DOMINGOS(6), Luiz Carlos de MATTOS(7),
} Andréa Regina Baptista ROSSIT(1), Carlos Eugênio CAVASINI(1) \& Ricardo Luiz Dantas MACHADO(1)

\begin{abstract}
SUMMARY
The transmission of malaria in Brazil is heterogeneous throughout endemic areas and the presence of asymptomatic Plasmodium sp. carriers (APCs) in the Brazilian Amazon has already been demonstrated. Malaria screening in blood banks is based on the selection of donors in respect to possible risks associated with travel or residence, clinical evidence and/or inaccurate diagnostic methods thereby increasing the probability of transfusion-transmitted infection. We evaluated the frequency of APCs in four blood services in distinct areas of the Brazilian Amazon region. DNA was obtained from 400 human blood samples for testing using the phenol-chloroform method followed by a nested-PCR protocol with species-specific primers. The positivity rate varied from 1 to $3 \%$ of blood donors from the four areas with an average of $2.3 \%$. All positive individuals had mixed infections for Plasmodium vivax and Plasmodium falciparum. No significant differences in the results were detected among these areas; the majority of cases originated from the transfusion centres of Porto Velho, Rondônia State and Macapá, Amapá State. Although it is still unclear whether APC individuals may act as reservoirs of the parasite, efficient screening of APCs and malaria patients in Brazilian blood services from endemic areas needs to be improved.
\end{abstract}

KEYWORDS: Plasmodium asymptomatic carriers; Blood Bank; Brazilian Amazon region.

\section{INTRODUCTION}

Malaria is an endemic disease in the Brazilian Amazon from known human malaria parasites. Plasmodium falciparum, Plasmodium vivax and Plasmodium malariae, have been detected in Brazil. P. vivax is the most common; it caused more than $80 \%$ of all cases reported in 2005. The transmission of malaria is heterogeneous throughout the endemic area ${ }^{6}$. The stability of malaria in these areas means that the prevalence of infection is high enough to produce clinical immunity within the population. On the other hand, propensity to evolve to epidemic status and high rate of severe disease in adults is correlated with unstable malaria. Indeed, clinical immunity to malaria within a population is a predictor; it is defined as the presence of an immune response that produces control, but without any signs of complete elimination of parasitemia or pathological consequences ${ }^{21}$. The increased prevalence of asymptomatic individuals with malaria carrying $P$. falciparum has been identified in areas of high transmission throughout the world ${ }^{3}$. In Brazil, studies carried out in indigenous ${ }^{5}$ and riverside ${ }^{1}$ communities of Rondônia State have demonstrated the existence of long-term asymptomatic Plasmodium sp. carriers (APCs), the majority of whom have low parasitaemia ${ }^{2}$. According to authors, native populations can act as a reservoir for the spread of malaria to migrants. In another study, conducted in a Mato Grosso State population, $32 \%$ of tested individuals were proved to be asymptomatic with $P$. malariae (single or mixed infections) within seventy-two hours after blood collection ${ }^{17}$. In the Amazonas State, $0.3 \%$ of blood donors evaluated in blood services presented with specific PCR-positivity for Plasmodium vivax ${ }^{19}$.

Although malaria transmission occurs principally through mosquito bites, there have been reports of transfusion-transmitted malaria since the beginning of the $20^{\text {th }}$ century. A review of international data published up to the end of the 1970s revealed an average of 145 cases per year. Although not common, transfusion-transmitted malaria may have very severe clinical implications if not detected and treated early ${ }^{11}$. Transmission of malaria has been reported to occur mainly with blood products from single donors, such as red cells, platelets and white cell concentrates ${ }^{20}$. Thus, the blood bank becomes a sufficiently important target to control this event, specifically in malaria endemic areas. On the other hand, the high rate of malaria without symptoms can be a great problem in the elaboration of malaria control strategies in the Brazilian Amazon region, which are essentially based on the treatment

(1) Departamento de Doenças Dermatológicas, Infecciosas e Parasitárias, Faculdade de Medicina de São José do Rio Preto, São José do Rio Preto, São Paulo, Brasil.

(2) Fundação HEMERON, Porto Velho, Rondônia, Brasil.

(3) Instituto de Hematologia e Hemoterapia do Amapá, Macapá, Amapá, Brasil.

(4) Fundação Centro de Hemoterapia e Hematologia do Pará, Belém, Pará, Brasil.

(5) Centro de Hematologia e Hemoterapia do Acre, Rio Branco, Acre, Brasil.

(6) Departamento de Biologia, Universidade Estadual Paulista, São José do Rio Preto, São Paulo, Brasil.

(7) Departamento de Biologia Molecular, Faculdade de Medicina de São José do Rio Preto, São José do Rio Preto, São Paulo, Brasil

Correspondence to: Prof. Dr. Ricardo Luiz Dantas Machado, Av. Brigadeiro Faria Lima 5416, 15090-000 São José do Rio Preto, SP, Brasil. Phone/Fax: +55.17.3201-5736. E-mail: ricardomachado@famerp.br 
FUGIKAHA, E.; FORNAZARI, P.A.; PENHALBEL, R.S.R.; LORENZETTI, A.; MAROSO, R.D.; AMORAS, J.T.; SARAIVA, A.S.; SILVA, R.U.; BONINI-DOMINGOS, C.R.; MATTOS, L.C.; ROSSIT, A.R.B.; CAVASINI, C.E. \& MACHADO, R.L.D. - Molecular screening of Plasmodium sp. asymptomatic carriers among transfusion centers from Brazilian Amazon region. Rev. Inst. Med. trop. S. Paulo, 49(1): 1-4, 2007.

of symptomatic patients ${ }^{1}$. The aim of this study is to evaluate the frequency of APCs in samples collected from four main Brazilian Amazon regional blood services.

\section{MATERIAL AND METHODS}

Blood donors, both men and women, from four blood banks of the Brazilian Amazon region $(\mathrm{n}=400)$, who were enrolled in our study, complied with the following criteria: over 18 years old, no previous malaria attack and no signs of malaria reported during the initial interview. Donors were screened using specific blood bank routinely performed protocols, which included the thick blood film technique in Porto Velho (PVL), Rondônia State and OPTIMAL ${ }^{\circledR}$ testing in Macapá (MCP), Amapá State. However, in Belém (BEL), Pará State and Rio Branco (RBR), Acre State, no Plasmodium screening test was performed; the donors were screened only by deferral guideline. Blood bank standard laboratory results were negative for each of the pathogens tested. Therefore, all study subjects herein considered provided accepted blood products.

DNA was extracted from the total blood using the phenolchloroform method ${ }^{9}$ and a nested-PCR protocol was followed using species-specific primers ${ }^{13}$. Epi Info version 6.04b (CDC, Atlanta, USA) was used for data storage and statistical analyses. To obtain independence among the proportions, the chi-square test with Yate's correction were applied with a $p$-value $<0.05$ being considered statistically significant. The protocol for this study was reviewed and approved by the Ethics Committee for research of the Medical School in São José do Rio Preto.

\section{RESULTS}

As summarized in Table 1, in spite of the negative results obtained by non-genotypic procedures the positivity rate varied from 1 to $3 \%$ of blood donors by using the molecular methodology. Overall, of the blood samples analyzed (100 from each region), nine positive cases $(2.3 \%)$ were identified, including three samples (3\%) from each of the blood banks in PVL and MCP, two from the service in BEL (2\%) and one from the blood bank in RBR (1\%). Even though no significant differences (Chi-square $p>0.05$ ) were detected among these areas, the majority of the positive cases originated from the blood banks in PVL and MCP. All the positive samples presented with mixed $P$. falciparum and $P$. vivax infections.

Table 1

Frequencies of Plasmodium sp. asymptomatic carriers and species as determined by malaria non-genotypic and genotypic screening tests among four transfusion centers from the Brazilian Amazon region

\begin{tabular}{lccc}
\hline Area & Malaria non- & \multicolumn{2}{c}{ NESTED-PCR } \\
& genotypic screening $^{\text {Frequency }}$ & Plasmodium sp. \\
\hline Macapá/AP & Negative $^{\mathrm{a}}$ & $3 / 100(3 \%)$ & $\mathrm{PF}+\mathrm{PV}$ \\
Porto Velho/RO & Negative $^{\mathrm{b}}$ & $3 / 100(3 \%)$ & $\mathrm{PF}+\mathrm{PV}$ \\
Belém/PA & Negative $^{\mathrm{c}}$ & $2 / 100(2 \%)$ & $\mathrm{PF}+\mathrm{PV}$ \\
Rio Branco/AC & Negative $^{\mathrm{d}}$ & $1 / 100(1 \%)$ & $\mathrm{PF}+\mathrm{PV}$ \\
\hline
\end{tabular}

$\mathrm{a}=$ OPTIMAL $^{\circledR} ; \mathrm{b}=$ thick blood film; $\mathrm{c}$ and $\mathrm{d}=$ deferral guidelines; $\mathrm{PF}=$

Plasmodium falciparum $; \mathrm{PV}=$ Plasmodium vivax

\section{DISCUSSION}

Malaria was one of the first recorded transfusion-transmitted infections and still is one of the most common. Differentiation of natural from transfusion-transmitted infections is very difficult in endemic $\operatorname{areas}^{12}$. Furthermore, in these areas, many of the donors are already infected with, or are at high risk of malaria infection. Our results emphasize the importance of testing for the presence of APCs in transfusion services from the Brazilian Amazon region.

The rapid and accurate diagnosis of malaria is essential and efficient chemotherapy is the main tool in the control of the disease ${ }^{14}$. Laboratorial diagnoses, in general, are made using the thick and thin blood film techniques. However, induced morphologic alterations can occur during the staining of slides, modifying the data of these species? ${ }^{7}$. Moreover, some parasitic development stages can lead to errors in diagnosis, even with extremely experienced microscopists. Microscopic diagnoses failed to detect low parasitemia in PCR-positive asymptomatic individuals living in endemic regions of Brazil ${ }^{17}$. The deficiency in the detection of mixed infections by the thin and thick blood film methods make treatment difficult as it is species-specific. Regarding the immunochromatographic test (used in MCP), we should not forget the limitations mentioned by the manufacturer OpitiMal$\mathrm{IT}^{\circledR}$, which include the test may not be one hundred percent accurate in samples with parasitemia of less than $100 \mathrm{red}$ blood cells $/ \mathrm{mm}^{3}$. Additionally, previous studies have shown that the immunochromatographic test is unreliable to detect $P$. malariae $^{10,15}$. In respect to the blood banks in BEL and RBR, the screening of donors only used deferral guidelines, in particular clinical evaluation, to carry out malaria diagnosis. We know that the overall effectiveness of any donation-screening program does, however, depend on evidence of clinical signs of malaria, but this criterion has important implications in APCs.

Polymerase chain reaction (PCR) is highly sensitive and specific and has shown to be efficient in the diagnosis of human malaria parasites, even identifying high prevalence of mixed infections ${ }^{16}$. Previous reports ${ }^{4,7}$ have demonstrated the superiority of the molecular method to the thick blood film technique. However PCR could have its limitations including its high cost and the necessity of adequate equipment and trained technicians. We believe, on the basis of our results, that detection of plasmodial DNA by the first step of nested$\mathrm{PCR}$, as has already been described in the detection of the Plasmodium genus ${ }^{13}$, would be enough to identify APCs with P. falciparum, P. vivax and P. malariae, thus reducing the costs of analysis in Brazilian blood banks. Furthermore, its cost-effectiveness was already approved in a Canadian study by a decision analysis model ${ }^{18}$. Additionally, the optimum strategy for minimizing the risk of transfusion-transmitted malaria in Brazilian endemic areas is a combination of appropriate donor selection together with donation screening using PCR and other laboratory methods.

According to the Brazilian Blood Donation policies, the control of transfusion-transmitted malaria infections comprises in the interviewing of blood donor candidates using deferral guidelines. Individuals can not donate for one year after a malaria attack or if they have any possible risk of malaria associated with travel or residency ${ }^{19}$. Although, documented cases of post-transfusion malaria have been reported ${ }^{11,12}$, 
FUGIKAHA, E.; FORNAZARI, P.A.; PENHALBEL, R.S.R.; LORENZETTI, A.; MAROSO, R.D.; AMORAS, J.T.; SARAIVA, A.S.; SILVA, R.U.; BONINI-DOMINGOS, C.R.; MATTOS, L.C.; ROSSIT, A.R.B.; CAVASINI, C.E. \& MACHADO, R.L.D. - Molecular screening of Plasmodium sp. asymptomatic carriers among transfusion centers from Brazilian Amazon region. Rev. Inst. Med. trop. S. Paulo, 49(1): 1-4, 2007.

it remains unclear whether ACPs may act as reservoirs of this protozoan ${ }^{12,17}$. Nevertheless, an experimental study with asymptomatic carriers blood found an infection rate in Anopheles darlingi (the main Brazilian vector) of $1.2 \%^{2}$ and plasma circulating nucleic acid concentrations have been shown to correlate with indices of prognostic significance in patients with acute pathologies ${ }^{8}$. The number of donors who have a potential risk of malaria is increasing, and there is a corresponding responsibility of collection teams to identify all such individuals with these conditions and pressure on the recruitment staff to replace lost donors ${ }^{12}$. Thus, efficient screening of APCs and/or malaria patients in blood banks from Brazilian endemic areas needs to be improved.

\section{RESUMO}

\section{Triagem molecular de portadores assintomáticos de Plasmodium sp. entre Bancos de Sangue da região Amazônica brasileira}

A transmissão da malária no Brasil é heterogênea em todas as áreas endêmicas e a presença de portadores assintomáticos de Plasmodium sp. (PAPs) na Amazônia brasileira já foi demonstrada. A triagem de pacientes maláricos em bancos de sangue é baseada na seleção dos doadores com relação aos riscos possíveis associados com residência, evidência clínica e/ou os métodos diagnósticos não acurados que aumentam a probabilidade da infecção transmitida por transfusão. Avaliamos a freqüência de PAPs em quatro bancos de sangue em áreas distintas da região Amazônica brasileira. O DNA foi obtido a partir de 400 amostras de sangue humano usando o método do fenol-clorofórmio, seguido por um protocolo de nested-PCR com oligonucleotídeos espécie-específicos. A taxa de positividade variou de 1 a 3\% de doadores do sangue das quatro áreas, com uma média de 2,3\%. Todos os indivíduos positivos tinham infecções mistas entre o Plasmodium vivax e o Plasmodium falciparum. Nenhuma diferença significativa nos resultados foi detectada entre estas áreas; a maioria dos casos originou dos Hemocentros de Porto Velho, do Estado de Rondônia e de Macapá, Estado do Amapá. Embora ainda não esteja claro se os indivíduos PAPs possam agir como reservatórios do parasito, a triagem eficiente de PAPs e de pacientes com malária em bancos de sangue no Brasil das áreas endêmicas necessita ser implementada.

\section{ACKNOWLEDGEMENTS}

We thank Valéria Fraga, Laurence Moretti and Luciana Conceição for help in laboratory assistance. This work was supported by Fundação de Amparo à Pesquisa do Estado de São Paulo (A.R.B.R and R.L.D.M.). The following institutions are also acknowledged: Faculdade de Medicina e Enfermagem de São José do Rio Preto (research studentship to E.F., A.L., R.S.R.P. and A.L), CNPq (research fellowship to P.A.F. and R.L.D.M.), Fundação Faculdade de Medicina de São José do Rio Preto (research fellowship to A.R.B.R. and R.L.D.M.).

\section{REFERENCES}

1. ALVES, F.P.; DURLACHER, R.R.; MENEZES, M.J. et al. - High prevalence of asymptomatic Plasmodium vivax and Plasmodium falciparum infections in native Amazonian populations. Amer. J. trop. Med. Hyg., 66: 641-648, 2002.
2. ALVES, F.P.; GIL, L.H.; MARRELLI, M.T. et al. - Asymptomatic carriers of Plasmodium sp. as infection source for malaria vector mosquitoes in Brazilian Amazon. J. med. Entomol., 42: 777-779, 2005.

3. BOTTIUS, E.; GUANZIROLLI, A.; TRAPE, J-F. et al. - Malaria: even more chronic in nature than previously thought; evidence for subpatent parasitemia detectable by the polimerase chain reaction. Trans. roy. Soc. trop. Med. Hyg., 90: 15-19, 1996.

4. BROWN, A.E.; KAIN, C.K.; PIPITHKUL, J. \& WEBSTER H.K. - Demonstration by the polymerase chain reaction of mixed Plasmodium falciparum and Plasmodium vivax undetected by conventional microscopy. Trans. roy. Soc. trop. Med. Hyg., 86: 609-612, 1992.

5. CAMARGO, E.P.; ALVES, F. \& PEREIRA DA SILVA, L.H. - Symptomless Plasmodium vivax infections in native Amazonians. Lancet, 353: 1415-1416, 1999.

6. CARTER, R.; MENDIS, K.N. \& ROBERTS, D. - Spatial targeting of interventious against malaria. Bull. Wld HIth Org., 78: 1401-1411, 2000.

7. CAVASINI, M.T.V.; RIBEIRO, W.L.; KAWAMOTO, F. \& FERREIRA, M.U. - How prevalent is Plasmodium malariae in Rondônia, Western Brazilian Amazon? Rev. Soc. bras. Med. trop., 33: 489-492, 2000.

8. CHIU, R.W.; RAINER, T.H. \& LO, Y.M. - Circulating nucleic acids: diagnostic applications for acute pathologies. Acta neurochir. (Wien), 95(suppl.): 471-474, 2005 .

9. FERREIRA, M.U.; LIU, Q.; KANEKO, O. et al. - Allelic diversity at the merozoite surface protein-1 locus of Plasmodium falciparum in clinical isolates from the southwestern Brazilian Amazon. Amer. J. trop. Med. Hyg., 59: 474-480, 1998.

10. GROBUSCH, M.P.; HÄNSCHEID, T.; ZOLLER, T.; JELINEK, T. \& BURCHARD, G.D. - Rapid immunochromatographic malarial antigen detection unreliable for detecting Plasmodium malariae and Plasmodium ovale. Europ. J. clin. Microbiol. infect. Dis., 21: 818-820, 2002.

11. KITCHEN, A.D.; BARBARA, J.A.J. \& HEWITT, P.E. - Documented cases of posttransfusion malaria occurring in England: a review in relation to current and proposed donor-selection guidelines. Vox Sang. (Basel), 89: 77-80, 2005.

12. KITCHEN, A.D. \& CHIODINI, P.L. - Malaria and blood transfusion. Vox Sang. (Basel), 90: 77-84, 2006.

13. KIMURA, M.; KNEKO, O.; LIU, Q. et al. - Identification of the four species of human malaria parasites by nested PCR that targets variant sequences in the small subunit rRNA gene. Parasit. Int., 46: 89-95, 1997.

14. MACHADO, R.L.D.; GARRET, D.O.; ADAGU, I.S.; WARHURST, D.C. \& PÓVOA M.M. - Simplified diagnosis of malaria infection; GFM/PCR/ELISA a simplified nucleic acid amplification technique by PCR/ELISA. Rev. Inst. Med. trop. S. Paulo, 40: 333-334, 1998.

15. MOODY, A. - Rapid diagnosis tests for malaria parasites. Clin. Microbiol. Rev., 15: 66$78,2002$.

16. POSTIGO, M.; MENDOZA-LÉON, A. \& PEREZ, H. A. - Malaria diagnosis by the polymerase chain reaction: a field study in south-eastern Venezuela. Trans. roy. Soc. trop. Med. Hyg., 92: 509-511, 1998.

17. SCOPEL, K.K.G.; FONTES, C.J.F.; NUNES, A.C.; HORTA, M.F. \& BRAGA, E.M. High prevalence of Plasmodium malariae infections in a Brazilian Amazon endemic area (Apiacás-Mato Grosso State) as detected by polymerase chain reaction. Acta trop., 90: 61-64, 2004.

18. SHEHATA, N.; KOHLI, M. \& DETSKY, A. - The cost-effectiveness of screening blood donors for malaria by PCR. Transfusion, 44: 217-228, 2004. 
FUGIKAHA, E.; FORNAZARI, P.A.; PENHALBEL, R.S.R.; LORENZETTI, A.; MAROSO, R.D.; AMORAS, J.T.; SARAIVA, A.S.; SILVA, R.U.; BONINI-DOMINGOS, C.R.; MATTOS, L.C.; ROSSIT, A.R.B.; CAVASINI, C.E. \& MACHADO, R.L.D. - Molecular screening of Plasmodium sp. asymptomatic carriers among transfusion centers from Brazilian Amazon region. Rev. Inst. Med. trop. S. Paulo, 49(1): 1-4, 2007.

19. TORRES, K.L.; FIGUEIREDO, D.V.; ZALIS, M.G. et al. - Standardization of a very specific and sensitive single PCR for detection of Plasmodium vivax in low parasitized individuals and its usefulness for screening blood donors. Parasit. Res., 17: 1-6, 2006

21. VINETZ, J. M. \& GILMAN, R.H. - Asymptomatic Plasmodium parasitemia and the ecology of malaria transmission. Amer. J. trop. Med. Hyg., 66: 639-640, 2002.

Received: 3 May 2006

Accepted: 16 August 2006

20. WYLIE, B.R. - Transfusion transmitted infection: viral and exotic disease. Anaesth intens. Care, 21: 24-30, 1993. 